\title{
Generation and Dissipation of Methyl Isothiocyanate in Soils Following Metam Sodium Fumigation: Impact on Verticillium Control and Potato Yield
}

\author{
Shachaf Triky-Dotan, Miriam Austerweil, and Bracha Steiner, Laboratory for Pest Management Research, Insti- \\ tute of Agricultural Engineering, ARO, the Volcani Center, P.O. Box 6, Bet Dagan 50250, Israel; Yitzhak Peretz- \\ Alon, Agricultural Committee, Maon Region Enterprises Israel; Jaacov Katan, Department of Plant Pathology and \\ Microbiology, the Hebrew University of Jerusalem, Faculty of Agricultural, Food and Environmental Quality Sci- \\ ences, Rehovot 76100, Israel; and Abraham Gamliel, Laboratory for Pest Management Research, Institute of Agri- \\ cultural Engineering, ARO, the Volcani Center, P.O. Box 6, Bet Dagan 50250, Israel
}

\begin{abstract}
Triky-Dotan, S., Austerweil, M., Steiner, B., Peretz-Alon, Y., Katan, J., and Gamliel, A. 2007. Generation and dissipation of methyl isothiocyanate in soils following metam sodium fumigation: Impact on Verticillium control and potato yield. Plant Dis. 91:497-503.

The fate of methyl isothiocyanate (MITC) was studied in agricultural soils following metam sodium (MS) application in a controlled system and under field conditions as it was related to disease control. Soil samples were collected from 34 field sites in Israel with no history of MS application. The generation and dissipation curves of MITC in these soils, under controlled conditions, varied significantly among the soils, as reflected by the concentration by time $(C \times T)$ product. This value was significantly related with the mortality level of Fusarium oxysporum $\mathrm{f}$. sp. radicis-lycopersici as a test organism and sand content of the soils. Seven field experiments were conducted in potato fields from 2001 to 2004. The MS treatments significantly reduced Verticillium wilt incidence and severity in five and four experiments, respectively, out of seven. Combining MS with formalin was more effective for controlling disease than MS alone in most cases. A significant relationship was found between mortality of $F$. oxysporum f. sp. radicislycopersici in soil samples to which MS was applied under controlled conditions and the incidence of Verticillium wilt disease in the field, and between $C_{\text {MITC }} \times T$ products and the incidence of Verticillium wilt disease in the field. These tests can be used for preplant assessment of potential MS efficacy.
\end{abstract}

Additional keywords: gas liquid chromatography, soil disinfestation, solid-phase microextraction, Verticillium dahliae

Verticillium wilt of potato, which is caused by Verticillium dahliae, is prevalent in Israel and in other countries. The plants are infected early during crop development, but disease symptoms (vascular discoloration and wilt) usually appear 75 to 80 days after planting (23). Early dying of the plants is usually accompanied by significant reduction of tuber yield (23). Soil fumigation with metam-sodium (MS) (sodium $N$-methyl dithiocarbamate) before planting is used to control soilborne diseases in Israel and worldwide, and is commonly applied by chemigation at about 600 liters $\mathrm{ha}^{-1}$ for controlling Verticillium wilt $(14,28)$. In moist soil, MS rapidly undergoes decomposition to the active ingredient, methyl isothiocyanate (MITC). In the vapor and liquid phase of the soil, MITC is toxic to soilborne pests,

Corresponding author: A. Gamliel

E-mail: agamliel@agri.gov.il

Accepted for publication 16 October 2006.

doi:10.1094/PDIS-91-5-0497

(C) 2007 The American Phytopathological Society especially fungi, and to some soil insects, ectoparasitic nematodes, and weeds $(16,24)$. The physical and chemical properties of MITC govern its movement and distribution in the soil following MS application. Its low water solubility $(0.76 \%$ [wt $/ \mathrm{wt}]$ at $\left.20^{\circ} \mathrm{C}\right)$, low vapor pressure $(21$ $\mathrm{mmHg}$ at $20^{\circ} \mathrm{C}$ ), and low Henry's constant $\left(\mathrm{K}_{\mathrm{H}} 0.011 \mathrm{air} /\right.$ water) limit its distribution in the soil atmosphere as compared with methyl bromide $(1,27)$.

Generation and dissipation of a pesticide in soil is affected by the physical-chemical properties of the soil, such as $\mathrm{pH}$, organic matter content, field water capacity, clay/sand/loam contents, and cation exchange capacity $(5,17,21)$. The half-life of MITC in soil is about 7 days (1). The generation and dissipation curve of MITC in soil follows first-order degradation kinetics and is controlled by microbial and physico-chemical processes $(6,15,16,25,32)$. The rate of MITC dissipation from soils increases with increasing soil organic content, temperature, and $\mathrm{pH}(2,10,15,16$, 29,32). In contrast, a longer period for MITC dissipation was reported in watersaturated soils or in soils that contained less than $20 \%$ clay $(2,16,29)$.
In some cases, MS fumigation is ineffective in controlling Verticillium wilt and stem rot in potatoes. Although accelerated degradation of MS following repeated application has been reported as a possible reason for the ineffective control of $V$. dahliae (9), the lower effectiveness of MS might also be related to its behavior and fate in these soils $(7,28)$.

The toxic effect of a pesticide on a pathogen under given conditions depends on the dosage $(C)$ and the exposure period $(T)$, and $C \times T$ is constant for any given pest/pathogen combination (19). This concept has been implemented by toxicologists in studying the effects of pesticides on insects $(18,22,26)$, nematodes (8), and fungi $(9,11,12,20)$. It is difficult, however, to correlate the laboratory results with those of field applications (21). In a previous study, we found a significant relationship between $C_{\text {MITC }} \times T$ products and mortality of pathogen in soil under controlled laboratory conditions (9).

The objectives of the present study were: (i) to characterize the generationdissipation curves of MITC in various agricultural soils following MS application, and their relationship to the effectiveness of control of a test organism; and (ii) to examine the relationships between data from the laboratory and those obtained in the field regarding the control of Verticillium wilt of potato.

\section{MATERIALS AND METHODS}

Soils. Soil samples were collected from 34 agricultural field sites in different locations in Israel. The soils had no history of MS application for at least 5 years prior to sampling. The chemical and physical properties of the soils are given in Table 1 . Soil samples were collected from the upper layer (5- to 20-cm depth) of the soil. Five subsamples of soil (total of $20 \mathrm{~kg}$ ) were mixed into one large composite sample, air-dried, and sieved through a 2-mm screen. The samples were stored in plastic containers at room temperature pending use (up to 3 weeks after collecting).

Application of MS in a controlled system. Fumigation containers were used to study the generation and dissipation curve of MITC in soil following MS application, 
as previously described (9). Each container was filled with $1 \mathrm{~kg}$ of soil. FORL assay soil was used for assessing the toxicity of the fumigant. This soil (soil 32) consists of natural inoculum of Fusarium oxysporum f. sp. radicis-lycopersici Jarvis \& Shoemaker (FORL) (chlamydospores in a naturally infested soil). Samples of this soil were air-dried, sieved through a 2-mm screen, placed in nylon-mesh bags ( $5 \mathrm{~g}$ of soil for each bag), and buried in the soil in each container before MS application. Three replicate containers were prepared for each MS treatment. The containers with the soil were vibrated for $1 \mathrm{~min}$ on a reciprocal vibrator $\left(2,000\right.$ strokes $\left.\mathrm{min}^{-1}\right)$ in order to achieve uniform soil compaction and aggregation in the container. MS (Edigan $37 \%$ a.i., Agan-Makhteshim Chemicals, Ashdod, Israel), at a rate in dry soil of $60 \mu \mathrm{g} \mathrm{g}^{-1}$, was prepared in an aqueous solution and was incorporated into the soil in each container in such a volume as to achieve $80 \%$ of the water-holding capacity of the treated soil. The containers with the treated soils were incubated at $25^{\circ} \mathrm{C}$ for 7 days, during which the change in MITC concentration over time was determined. Thereafter, the containers were opened and aerated and the inoculum bags were retrieved for viability assays. Soil containers that were prepared essentially identically, but without MS application, served as nontreated controls.

Assessment of the generation and dissipation of MITC in soil. Concentration of MITC in the headspace of the containers was conducted by means of solid-phase micro-extraction (SPME) and gas chromatography (GC) as described previously $(4,9)$. The lower detection limit of MITC by this analytical method is $0.65 \mathrm{ng} \mathrm{cm}^{-3}$. The $C \times T$ product of MITC (expressed as $\mu \mathrm{g} \mathrm{h} \mathrm{cm}^{-3}$ ) was calculated as the area under the MITC concentration curve over time $(9,11,12)$. Since MITC concentrations could only be determined at finite time intervals, the integration was calculated numerically according to the trapezoidal rule (30).
Viability assays. The population density of $F$. oxysporum f. sp. radicis-lycopersici was assessed by the soil-dilution-plating technique (11). Each of three 2.5-g soil subsamples from each replicate was added to $22.5 \mathrm{ml}$ of sterile water agar $(0.1 \%$ $\mathrm{wt} / \mathrm{vol})$ containing $\mathrm{MgSO}_{4} \cdot 7 \mathrm{H}_{2} \mathrm{O} \quad(0.1 \%$ $\mathrm{wt} / \mathrm{vol})$. The samples were shaken for 1 min with Bag mixer (BagMixer 400, Interscience, St Nom-La-Breteche, France) at eight strokes per second, and then serially diluted with the same solution. Aliquots of $0.2 \mathrm{ml}$ from each dilution were spread onto the surface of agar in four petri dishes that contained a modified peptone pentachloronitrobenzene selective agar medium (13). The plates were incubated in the dark at $28^{\circ} \mathrm{C}$ for 4 to 6 days. Randomly selected colonies of $F$. oxysporum isolates that originated from the soil were tested for pathogenicity on tomato transplants, in order to verify their identity as $F$. oxysporum f. sp. radicis-lycopersici (12). The results are expressed as CFU per gram of soil that had been dried at $105^{\circ} \mathrm{C}$ for

Table 1. Physical and chemical properties of soils, methyl isothiocyanate (MITC) concentration $(C)$ by time $(T)$ products $\left(C_{\mathrm{MITC}} \times T\right)$ following metam sodium (MS) application, and mortality of Fusarium oxysporum f. sp. radicis-lycopersici in 34 soils treated with MS at $60 \mu 1 \mathrm{~g}^{-1}$ soil

\begin{tabular}{|c|c|c|c|c|c|c|c|c|c|c|}
\hline \multirow[b]{2}{*}{ Soil no. } & \multicolumn{7}{|c|}{ Soil properties } & \multicolumn{2}{|c|}{ Chemical assay } & \multirow{2}{*}{$\begin{array}{c}\text { Bioassay } \\
\begin{array}{c}\text { Mortality } \\
(\%)^{y}\end{array}\end{array}$} \\
\hline & Site $^{\mathrm{u}}$ & Type $^{\mathrm{v}}$ & $\begin{array}{c}\text { Organic } \\
\text { matter }(\%)\end{array}$ & $\begin{array}{c}\text { Clay } \\
(\%)\end{array}$ & $\begin{array}{l}\text { Silt } \\
(\%)\end{array}$ & $\begin{array}{c}\text { Sand } \\
(\%)\end{array}$ & pH & $\begin{array}{c}C_{\mathrm{MITC} \times T \text { products }} \\
\quad\left(\mu \mathrm{g} \mathrm{h} \mathrm{cm}^{-3}\right)^{\mathrm{w}}\end{array}$ & $\underset{\left(\mu \mathrm{g} \mathrm{cm}^{-3}\right)^{\mathrm{x}}}{\operatorname{Max} C_{\mathrm{MITC}}}$ & \\
\hline 1 & Mehola & $\mathrm{SiCL}$ & 0.7 & 31 & 58 & 11 & 7.8 & 2.16 & 0.129 & 0.0 \\
\hline 2 & Naama & Si L & 0.5 & 16 & 42 & 42 & 7.2 & 2.28 & 0.132 & 17.2 \\
\hline 3 & Beeri & $\mathrm{L}$ & 0.7 & 15 & 35 & 50 & 8.2 & 2.93 & 0.183 & 16.6 \\
\hline 4 & Tomer & Si L & 0.7 & 32 & 51 & 17 & 7.5 & 4.35 & 0.151 & 9.2 \\
\hline 5 & Ramat Hagolan & $\mathrm{C}$ & 1.9 & 57 & 35 & 8 & 7.6 & 4.38 & 0.162 & 9.0 \\
\hline 6 & En Hashelosha & $\mathrm{Sa} \mathrm{L}$ & 1.8 & 16 & 30 & 54 & 7.8 & 5.04 & 0.134 & 0.0 \\
\hline 7 & Upper Galilee & $\mathrm{Nt}^{\mathrm{z}}$ & $\mathrm{Nt}$ & $\mathrm{Nt}$ & $\mathrm{Nt}$ & $\mathrm{Nt}$ & $\mathrm{Nt}$ & 5.16 & 0.162 & 0.0 \\
\hline 8 & Nirim & $\mathrm{Sa} \mathrm{L}$ & 0.5 & 13 & 35 & 52 & 7.5 & 5.64 & 0.232 & 0.0 \\
\hline 9 & Bet Dagan & $\mathrm{L}$ & 0.6 & 26 & 29 & 45 & 7.4 & 5.73 & 0.158 & 0.0 \\
\hline 10 & Bet Uzziel & $\mathrm{Nt}$ & $\mathrm{Nt}$ & $\mathrm{Nt}$ & $\mathrm{Nt}$ & $\mathrm{Nt}$ & $\mathrm{Nt}$ & 7.10 & 0.366 & 12.3 \\
\hline 11 & Bet Shean & $\mathrm{SiC}$ & 0.6 & 47 & 45 & 8 & 8.1 & 9.06 & 0.164 & 94.0 \\
\hline 12 & Bene Ziyyon & $\mathrm{Sa}$ & 0.1 & 7 & 3 & 90 & 7.4 & 9.46 & 0.200 & 60.8 \\
\hline 13 & Talme Yosef & $\mathrm{Nt}$ & $\mathrm{Nt}$ & $\mathrm{Nt}$ & $\mathrm{Nt}$ & $\mathrm{Nt}$ & $\mathrm{Nt}$ & 11.20 & 0.264 & 55.3 \\
\hline 14 & Gelil Yam & $\mathrm{Sa}$ & 0.9 & 6 & 7 & 87 & 7.5 & 11.40 & 0.272 & 65.3 \\
\hline 15 & Mishmeret & $\mathrm{Sa}$ & 0.1 & 5 & 3 & 92 & 8.0 & 11.78 & 0.328 & 59.5 \\
\hline 16 & Magen & $\mathrm{Sa} L$ & 0.2 & 7 & 28 & 65 & 8.0 & 11.80 & 0.197 & 95.6 \\
\hline 17 & Ofaqim & $\mathrm{L} \mathrm{Sa}$ & 0.3 & 4 & 18 & 78 & 8.0 & 11.91 & 0.204 & 62.0 \\
\hline 18 & Alumim & $\mathrm{L} \mathrm{Sa}$ & 0.3 & 6 & 11 & 83 & 8.0 & 12.70 & 0.267 & 60.0 \\
\hline 19 & $\mathrm{Nir} \mathrm{Oz}$ & $\mathrm{Sa} \mathrm{L}$ & 0.3 & 11 & 18 & 71 & 8.0 & 14.50 & 0.351 & 80.0 \\
\hline 20 & Maslul & $\mathrm{Sa} \mathrm{L}$ & 1.0 & 9 & 21 & 70 & 8.1 & 16.70 & 0.327 & 96.9 \\
\hline 21 & Yotvata & $\mathrm{L} \mathrm{Sa}$ & 0.5 & 10 & 10 & 80 & 7.7 & 20.26 & 0.265 & 100.0 \\
\hline 22 & Nordiyya & $\mathrm{Sa}$ & 0.2 & 7 & 3 & 90 & 7.6 & 20.42 & 0.366 & 96.3 \\
\hline 23 & Gevulot & $\mathrm{Sa} \mathrm{L}$ & 0.2 & 5 & 21 & 74 & 7.9 & 23.72 & 0.256 & 100.0 \\
\hline 24 & Zur Moshe & $\mathrm{Sa}$ & 0.3 & 5 & 5 & 90 & 7.3 & 26.14 & 0.259 & 100.0 \\
\hline 25 & Ramat Hanegev & $\mathrm{Sa} \mathrm{L}$ & 0.4 & 10 & 22 & 68 & 7.7 & 28.18 & 0.258 & 100.0 \\
\hline 26 & Zofar & $\mathrm{L} \mathrm{Sa}$ & 0.2 & 3 & 22 & 75 & 7.8 & 28.27 & 0.258 & 100.0 \\
\hline 27 & Besor & $\mathrm{L} \mathrm{Sa}$ & 0.2 & 7 & 17 & 76 & 7.8 & 31.32 & 0.302 & 100.0 \\
\hline 28 & Zeelim & $\mathrm{Sa}$ & 0.2 & 4 & 5 & 91 & 7.4 & 32.64 & 0.329 & 100.0 \\
\hline 29 & Yanuv & $\mathrm{Sa}$ & 0.1 & 7 & 2 & 91 & 7.5 & 37.60 & 0.312 & 100.0 \\
\hline 30 & En Yahav & $\mathrm{L} \mathrm{Sa}$ & 0.1 & 5 & 12 & 83 & 7.8 & 38.09 & 0.297 & 100.0 \\
\hline 31 & Rehovot & $\mathrm{Sa}$ & 0.1 & 4 & 2 & 94 & 7.9 & 40.32 & 0.357 & 100.0 \\
\hline 32 & En Tamar & $\mathrm{Sa}$ & 0.1 & 4 & 7 & 89 & 8.1 & 42.89 & 0.342 & 100.0 \\
\hline 33 & Hazeva & $\mathrm{Sa}$ & 0.0 & 3 & 11 & 86 & 8.0 & 44.88 & 0.355 & 100.0 \\
\hline 34 & Eilot & $\mathrm{Sa} \mathrm{L}$ & 0.2 & 10 & 36 & 54 & 6.9 & 54.76 & 0.484 & 100.0 \\
\hline
\end{tabular}

" Field experiments were conducted in soils $3,6,17,18,31,32$

${ }^{v}$ Soil type: $\mathrm{C}=$ clay, $\mathrm{L}=$ loam, $\mathrm{Sa}=$ sandy, $\mathrm{Si}=$ silt.

${ }^{w}$ MITC concentration was measured periodically during the fumigation process. A gas-generation and dissipation-concentration curve was drawn for each soil. $C_{\mathrm{MITC}} \times T$ products were calculated by integrating the area under the curve for $152 \mathrm{~h}$ of incubation.

${ }^{x}$ Maximum MITC concentration measured.

${ }^{\text {y }}$ Chlamydospores of $F$. oxysporum f. sp. radicis-lycopersici pouched in nylon net bags were buried in soil before MS application. Bags were retrieved after 14 days, and mortality was calculated by comparison with viability of propagules in nontreated soil.

${ }^{\mathrm{z}} \mathrm{Nt}=$ not tested. 
$48 \mathrm{~h}$. The percent mortality was calculated by comparison with the population in the nontreated containers.

Experimental setup of field trials. Seven field experiments were conducted in southwestern Israel from 2001 to 2004. The chemical and physical properties of the soils are summarized in Table 1. The common crop-rotation system for these fields was a 4-year rotation scheme with a winter potato crop (first year), followed by fallow (second year), wheat (third year), and peanut (fourth year). All the fields had a history of two or three potato cropping. The fields were naturally infested with $V$. dahliae, and various levels of damage had been recorded in the previous potato crops. Experiments 1 and 2 were initiated in fall 2001 and fall 2002 at Beeri; experiment 3 was conducted in fall 2002 at Alumim; and experiments 4 to 7 were initiated in fall 2003 at four sites: Alumim, Beeri, En Hashelosha, and Ofaqim. Prior to fumigant application in the field, soil samples were collected from each field and tested under controlled conditions, by adding MS, to obtain generation and dissipation curve of MITC, and to assess the mortality of $F$. oxysporum f. sp. radicis-lycopersici as a test organism. In all experiments, each plot consisted of 18 beds, each $96 \mathrm{~cm}$ wide by $36 \mathrm{~m}$ long. The six central beds were used for data collection. Fumigation treatments were arranged in a randomized complete block design with four replications per treatment. The fumigants were applied at the end of August in each year. The treatments were application of MS (600 liters $\mathrm{ha}^{-1}$ ) and a mixture of MS plus formalin (ForDor 37, Dor Chemicals, Haifa, Israel) at rates of 600 liters $\mathrm{ha}^{-1}$ and 2,500 liters $\mathrm{ha}^{-1}$, respectively. Chemicals were applied by chemigation through a sprinkler irrigation system at a water volume of $400 \mathrm{~m}^{3}$ $\mathrm{ha}^{-1}$. Fumigation with an MS-formalin mixture is a common practice in potato fields for controlling a wide spectrum of potato pathogens, including fungi and bacteria (14). Nontreated plots served as controls. Nylon net bags containing soil naturally infested with chlamydospores of $F$. oxysporum f. sp. radicis-lycopersici (soil 32) were buried in the center of each plot at depths of 20 and $40 \mathrm{~cm}$ prior to fumigation. The bags were retrieved from the soil 14 days after fumigation, and the viability of the organism was assessed as described above to provide an additional parameter for evaluating the efficacy of the treatments.

Cultural practices. A fall crop of potatoes (Solanum tuberosum L. cv. Marabel, Hevel Maon Seeds, Israel) was planted in all the fields between 20 September and 10 October of the relevant year for each experiment. The seed tubers were planted at a depth of $15 \mathrm{~cm}$ with a commercial planter, one row per bed. The fields were sprinkle-irrigated and farmed according to the recommendations for commercial potato production in this region.
Assessment of Verticillium wilt and tuber yield. Batches of 50 potato stems were periodically sampled from each plot. The stems were rated for vascular discoloration and wilt severity on a scale of 0 to 3 , in which $0=$ no vascular system discoloration and $3=$ wilted plants with microsclerotia on the stem. Stem colonization by $V$. dahliae was confirmed by placing pieces of infected stems on a Verticilliumselective agar medium (3) and incubating the plates for 21 days at $18^{\circ} \mathrm{C}$. The crop foliage in each experiment was desiccated after 120 days of growth in all experiments, and the tubers were left in the soil for an additional 3 weeks to allow the skin to mature. The tubers were manually harvested from $6 \mathrm{~m}$ of two adjacent rows at the center of each plot. Tubers were counted and graded according to standard marketable size.

Statistical analyses. All laboratory experiments were carried out at least twice. Data that were taken as percentages were arcsine-transformed before analysis. Nonparametric variables, such as disease severity, were analyzed using the rank procedure followed by analysis of variance. Separate analyses of each experiment showed homogeneous variances of the experimental error between the repeats. All treatment means were compared simultaneously by Tukey's protected test for significant differences. In each experiment in which the amount of fumigant was measured, the residual amount of fumigant was plotted against incubation time. Regression analyses were also applied. All analyses were performed with the SAS software

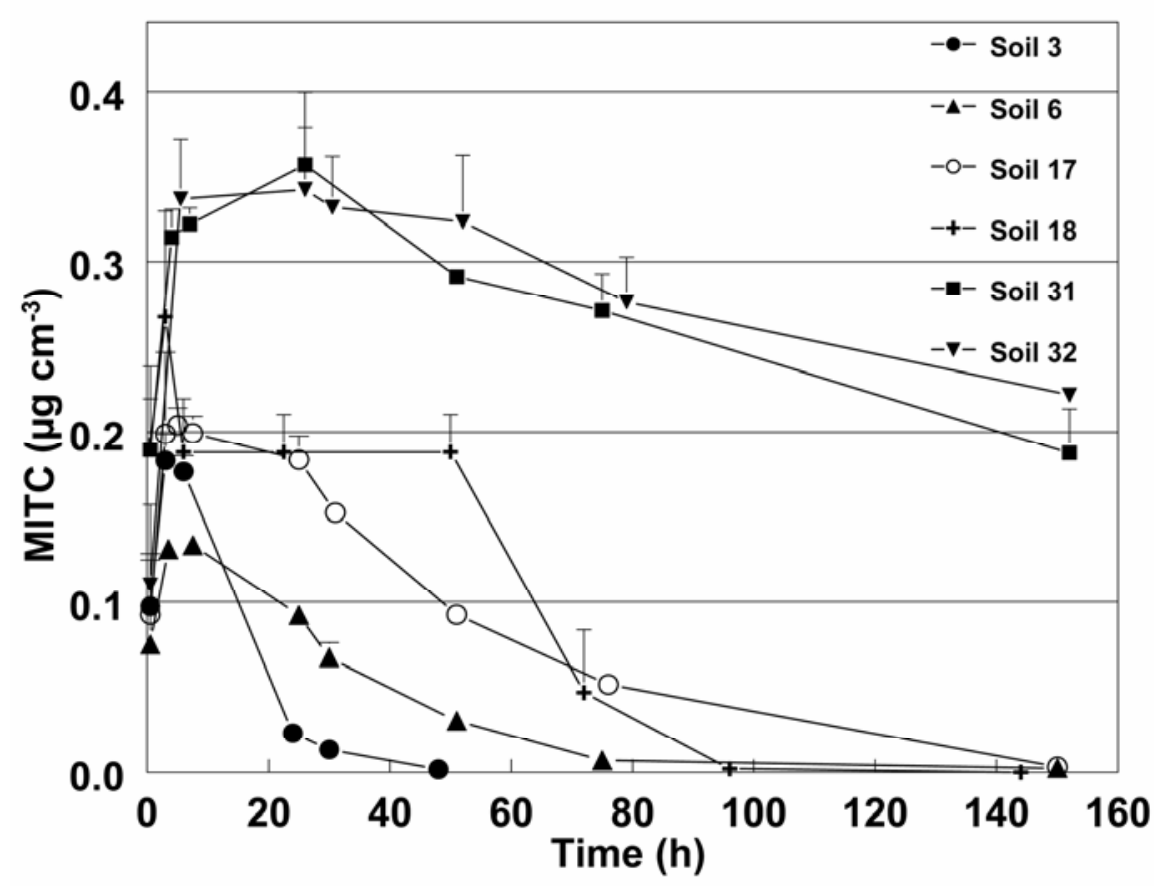

Fig. 1. Generation and dissipation of methyl isothiocyanate (MITC) in soils after application of metam sodium (MS) $\left(60 \mu \mathrm{g} \mathrm{g}^{-1}\right)$. Curves are representative of the range obtained from 34 soil samples. Soil numbers refer to the list of soils in Table 1 . The soils had no history of MS application in the prior 5 years. Vertical bars indicate SD.
(SAS Institute, Cary, NC; release 8.01 for PC) at $P \leq 0.05$.

\section{RESULTS}

Generation and dissipation of MITC in soils and mortality of the test organism. The generation and dissipation curves of MITC under controlled conditions varied significantly among the soils tested (Fig. 1). Figure 1 illustrates the diversity among MITC concentration curves for six representative soils, which were further tested in the field. The maximum MITC concentration was recorded 5 to $6 \mathrm{~h}$ after MS application in most of the tested soils, and was followed by a gradual decrease. In general, MITC was detectable for 3 to 7 days, depending on the soil. For example, in Rehovot soil (soil 31), MITC concentrations remained high $\left(0.2 \mu \mathrm{g} \mathrm{h} \mathrm{cm}^{-3}\right)$ after 6 days. Moreover, in En Tamar soil (soil 32), MITC was detectable even after 4 weeks (data not shown). This soil is located in the southern part of the Syria-Africa rift, which is characterized by hot summer temperatures; therefore, potato is not grown in this region. In contrast, in some soils, e.g., Beeri (soil 3), MITC rapidly dissipated below the detectable level within $48 \mathrm{~h}$ after application.

Data on the $C_{\text {MITC }} \times T$ product were calculated from the area under the MITC generation-dissipation curve for each soil and are presented in an ascending order in Table 1 . A high $C_{\text {MITC }} \times T$ product might be the result of a high MITC concentration, a slow dissipation rate, or both. A wide range of $C_{\mathrm{MITC}} \times T$ products was obtained for the soils tested; the least was 
$2.16 \mu \mathrm{g} \mathrm{h} \mathrm{cm}^{-3}$ at Mehola (soil 1) and the greatest was $54.76 \mu \mathrm{g} \mathrm{h} \mathrm{cm}{ }^{-3}$ at Elot (soil 34).

The value of the $C_{\text {MITC }} \times T$ product is also reflected in the mortality of $F$. oxysporum $\mathrm{f}$. sp. radicis-lycopersici, the test organism (Table 1). A significant linear regression was established $(P=0.005)$ between $C_{\text {MITC }} \times T$ products and mortality level of the pathogen (Fig. 2). This trend indicates that the effect of $C_{\text {MITC }} \times T$ product on mortality is linearly cumulative. Mortality data indicate a critical value of $17 \mu \mathrm{g} \mathrm{h} \mathrm{cm}^{-3}$ for the $C_{\text {MITC }} \times T$ product; above this value, complete control of the test pathogen was obtained (with the exception of soil 22); values between 10 and $17 \mu \mathrm{g} \mathrm{h} \mathrm{cm}^{-3}$ yielded partial control; and at values below $10 \mu \mathrm{g} \mathrm{h} \mathrm{cm}$ there was no effect on pathogen viability (Table 1).

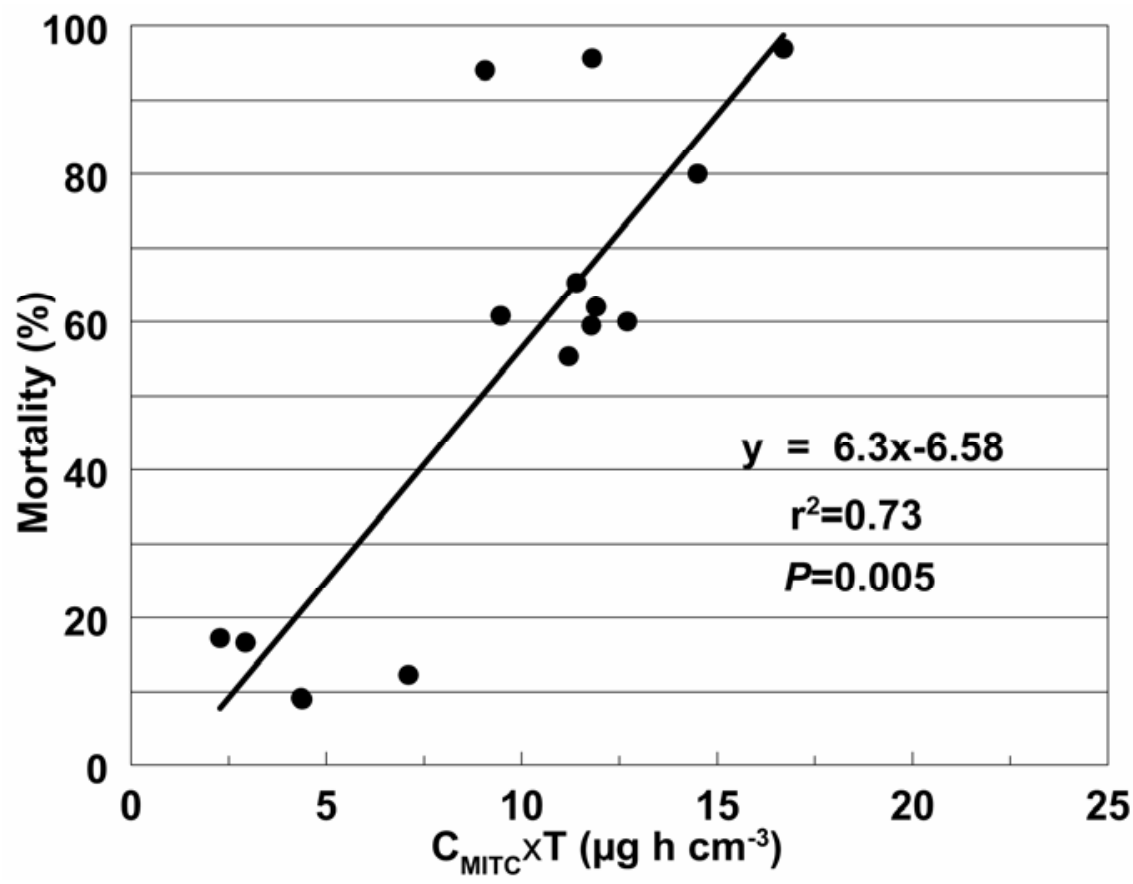

Fig. 2. Relationship between methyl isothiocyanate (MITC) concentration by time $\left(C_{\mathrm{MITC}} \times T\right)$ product calculated from the area under the generation-dissipation curve for each soil, and the mortality of Fusarium oxysporum f. sp. radicis-lycopersici in assay soil.

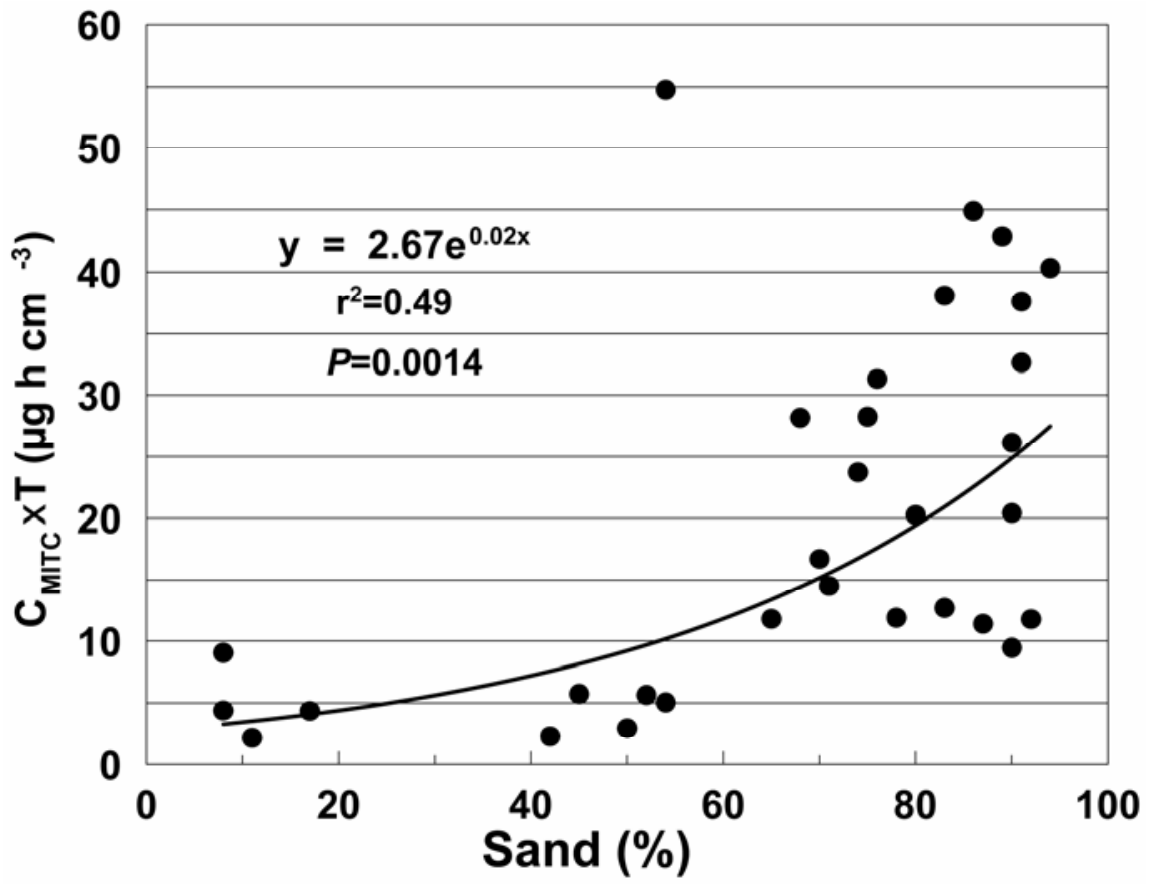

Fig. 3. Relationship between percentage of sand in a soil sample and values of concentration by time $\left(C_{\text {MITC }} \times T\right)$ products of methyl isothiocyanate $($ MITC) calculated from area under the generationdissipation curve for each soil.
An exponential regression was established between sand content of the soils and the $C_{\text {MITC }} \times T$ products (Fig. 3), with a very low $C_{\mathrm{MITC}} \times T$ product obtained in soils with sand content less than $60 \%$. No significant relationship was found between $C_{\text {MITC }} \times T$ products and other soil properties, including organic matter, clay and silt contents, and $\mathrm{pH}, r^{2}$ being $<0.49$ (results not shown).

Effect of MS application in fields on the incidence and severity of Verticillium wilt disease. The MS treatments significantly reduced disease incidence and severity, compared with those in nontreated controls, in five and four experiments, respectively, out of seven (Table 2). Disease was reduced by up to $63 \%$ (in experiment 3). The combined MS-formalin treatment was more effective than MS alone; it reduced disease incidence and severity in all experiments and in most cases resulted in significantly lower disease values than MS alone. In experiments 5 and 6, where MS alone had a negligible control effect, the combined treatment significantly reduced the disease. In four cases, combined treatment was more effective in increasing potato yield compare with nontreated plots, but it was not significantly more effective than MS alone.

The greater effectiveness of the MSformalin combination was also reflected in the mortality of $F$. oxysporum f. sp. radicis-lycopersici in assay soil when it was tested under field conditions (Table 2). Thus, MS alone and the combined treatment reduced pathogen viability, compared with nontreated controls, in three and five experiments, respectively, out of seven.

Relationship between tests under controlled conditions and disease incidence and severity in the potato fields. A significant linear regression $(P=0.0007)$ was established between mortality of $F$. $o x$ ysporum f. sp. radicis-lycopersici in soil samples from a field to which MS had been applied under controlled conditions, and the incidence of Verticillium wilt in the field from which the samples had come, 90 days after planting (Fig. 4A). A similar linear regression was obtained regarding disease severity $\left(r^{2}=0.88, P=\right.$ 0.0166 , not shown). No significant relationship was established between mortality of the test organism in the field during MS fumigation and the incidence of Verticillium wilt (Fig. 4B) or disease severity (results not shown). A significant linear regression was established $(P=0.0046)$ between $C_{\text {MITC }} \times T$ products calculated from MITC generationdissipation curves under controlled conditions (Table 1) and the incidence of Verticillium wilt in field experiments, 110 days after planting (Fig. 5), and disease severity (results not shown).

\section{DISCUSSION}

Our studies show that the behavior of MS regarding its generation and dissipa- 
tion differ among soils. The level of persistence of MS in soil, as reflected in the $\mathrm{C}_{\text {MITC }} \times \mathrm{T}$ products, was related to the level of mortality of the test organism in the laboratory and to disease control in the field. The generation and dissipation curves of MITC in soils can serve as tests for assessing and predicting the effectiveness of MS fumigation in those soils.

The maximum concentrations of MITC in most of the tests soils were recorded 5 to $6 \mathrm{~h}$ after MS application, and were followed by a gradual decrease (Fig. 1). The dissipation of MITC in soils following MS application is affected by microbial processes and by the physical-chemical properties of the soil $(6,16,25,32)$. Studies elsewhere showed that the loss of MITC from soils increased with increases in soil temperature, addition of lime to acid soils, amendment with chicken manure, and with high organic matter content. In contrast, slow dissipation rates were reported in water-saturated soils or those that contained less than $20 \%$ clay $(2,10,15$, $16,29,31)$. Most of the Israeli soils tested are alkaline $(\mathrm{pH}=6.9$ to 8.2$)$ with low organic matter contents (0.0 to $1.9 \%)$. Apparently, this narrow range of differences was not sufficient to produce a significant relation between soil properties and $C_{\text {MITC }} \times T$ products, except for sand content (Fig. 3).

The differences among generationdissipation curves of toxicants can be best expressed by the $C \times T$ product. Indeed, in the present study, a high $C_{\text {MITC }} \times T$ product indicated a high MITC peak and a slow dissipation rate; the level of the $C_{\text {MITC }} \times T$ product was also related to the mortality of the test organism (Fig. 2). The F. oxysporum f. sp. radicis-lycopersici mortality results indicated a critical value of the

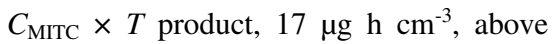
which complete control of the test organism was obtained (with the exception of soil 22). We found in previous laboratory
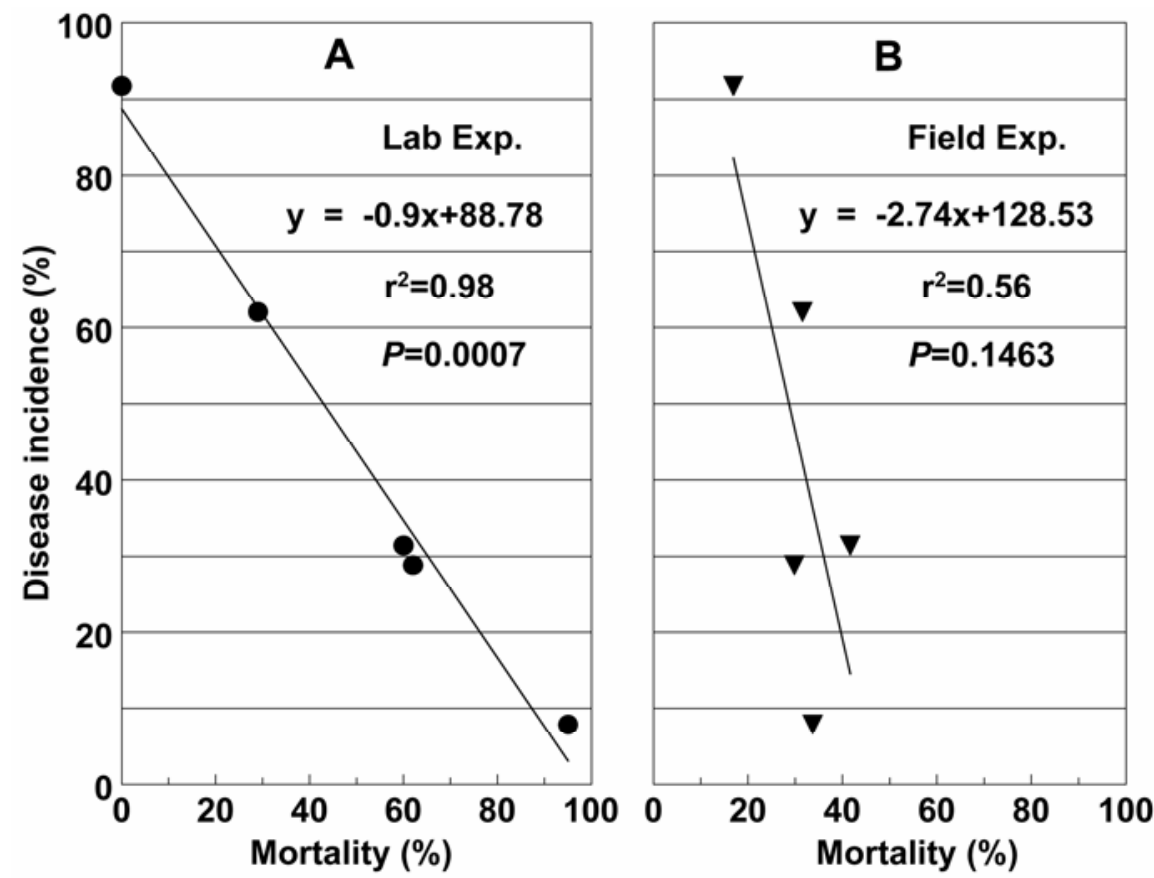

Fig. 4. Relationship between mortality of Fusarium oxysporum f. sp. radicis-lycopersici in assay soil under controlled (A) or field conditions (B) and incidence of Verticillium wilt 90 days after planting. Mortality of $F$. oxysporum $\mathrm{f}$. sp. radicis-lycopersici was calculated by comparison with a nontreated soil sample.

Table 2. Effect of metam sodium (MS) application in seven field experiments (Exp.) on mortality of Fusarium oxysporum f. sp. radicis-lycopersici, incidence and severity of Verticillium wilt, and potato yield

\begin{tabular}{|c|c|c|c|c|c|c|c|}
\hline Exp. & Site & Year & Treatment & Mortality $(\%)^{\mathrm{w}}$ & $\begin{array}{c}\text { Disease } \\
\text { incidence }(\%)^{\mathrm{x}}\end{array}$ & $\begin{array}{c}\text { Disease } \\
\text { severity rating }\end{array}$ & $\begin{array}{l}\text { Potato tuber } \\
\text { yield }\left(\mathrm{kg} \mathrm{m}^{-2}\right)^{\mathrm{y}}\end{array}$ \\
\hline \multirow[t]{3}{*}{1} & Beeri & 2001-2002 & Nontreated & $0.0 \mathrm{a}^{\mathrm{z}}$ & $100.00 \mathrm{a}$ & $2.23 \mathrm{a}$ & $2.65 \mathrm{~b}$ \\
\hline & & & MS & $95.5 \mathrm{~b}$ & $60.00 \mathrm{~b}$ & $0.70 \mathrm{~b}$ & $3.61 \mathrm{ab}$ \\
\hline & & & MS+Formalin & $84.4 \mathrm{~b}$ & $35.00 \mathrm{~b}$ & $0.43 \mathrm{~b}$ & $4.10 \mathrm{a}$ \\
\hline \multirow[t]{3}{*}{2} & Beeri & $2002-2003$ & Nontreated & $0.0 \mathrm{a}$ & $91.70 \mathrm{a}$ & $1.81 \mathrm{a}$ & $2.52 \mathrm{~b}$ \\
\hline & & & MS & $88.8 \mathrm{~b}$ & $63.90 \mathrm{~b}$ & $0.69 \mathrm{~b}$ & $3.93 \mathrm{a}$ \\
\hline & & & MS+Formalin & $98.7 \mathrm{~b}$ & $15.30 \mathrm{c}$ & $0.23 \mathrm{c}$ & $3.94 \mathrm{a}$ \\
\hline \multirow[t]{3}{*}{3} & Alumim & $2002-2003$ & Nontreated & $0.0 \mathrm{a}$ & $95.60 \mathrm{a}$ & $2.10 \mathrm{a}$ & $3.03 \mathrm{a}$ \\
\hline & & & MS & $33.7 \mathrm{a}$ & $37.10 \mathrm{~b}$ & $0.40 \mathrm{~b}$ & $3.25 \mathrm{a}$ \\
\hline & & & MS+Formalin & $41.0 \mathrm{a}$ & $49.40 \mathrm{~b}$ & $0.60 \mathrm{~b}$ & $3.34 \mathrm{a}$ \\
\hline \multirow[t]{3}{*}{4} & Alumim & 2003-2004 & Nontreated & $0.0 \mathrm{a}$ & $100.00 \mathrm{a}$ & $2.38 \mathrm{a}$ & $3.85 \mathrm{~b}$ \\
\hline & & & MS & $41.6 \mathrm{~b}$ & $46.41 \mathrm{~b}$ & $0.56 \mathrm{~b}$ & $5.10 \mathrm{a}$ \\
\hline & & & MS+Formalin & $92.4 \mathrm{~b}$ & $23.95 \mathrm{c}$ & $0.28 \mathrm{~b}$ & $5.03 \mathrm{a}$ \\
\hline \multirow[t]{3}{*}{5} & Beeri & 2003-2004 & Nontreated & $0.0 \mathrm{a}$ & $100.00 \mathrm{a}$ & $3.00 \mathrm{a}$ & $3.06 \mathrm{a}$ \\
\hline & & & MS & $31.5 \mathrm{ab}$ & $100.00 \mathrm{a}$ & $2.43 \mathrm{ab}$ & $2.68 \mathrm{a}$ \\
\hline & & & MS+Formalin & $79.6 \mathrm{~b}$ & $77.84 \mathrm{~b}$ & $1.26 \mathrm{~b}$ & $3.63 \mathrm{a}$ \\
\hline \multirow[t]{3}{*}{6} & En Hashelosha & 2003-2004 & Nontreated & $0.0 \mathrm{a}$ & 96.59 a & $2.38 \mathrm{a}$ & $3.54 \mathrm{~b}$ \\
\hline & & & MS & $17.0 \mathrm{a}$ & $91.75 \mathrm{a}$ & $1.79 \mathrm{a}$ & $4.07 \mathrm{ab}$ \\
\hline & & & MS+Formalin & $92.0 \mathrm{a}$ & $30.50 \mathrm{~b}$ & $0.39 \mathrm{~b}$ & $4.36 \mathrm{a}$ \\
\hline \multirow[t]{3}{*}{7} & Ofaqim & 2003-2004 & Nontreated & $0.0 \mathrm{a}$ & $92.07 \mathrm{a}$ & $1.40 \mathrm{a}$ & $3.71 \mathrm{a}$ \\
\hline & & & MS & $29.8 \mathrm{ab}$ & $59.18 \mathrm{~b}$ & $0.71 \mathrm{a}$ & $3.78 \mathrm{a}$ \\
\hline & & & MS+Formalin & $99.5 \mathrm{~b}$ & $11.04 \mathrm{c}$ & $0.12 \mathrm{~b}$ & $4.50 \mathrm{a}$ \\
\hline
\end{tabular}

${ }^{\text {w}}$ Chlamydospores of $F$. oxysporum f. sp. radicis-lycopersici pouched in nylon net bags were buried in the field plot before MS application. Bags were retrieved after 14 days, and mortality was calculated by comparison with viability of propagules in nontreated soil.

${ }^{\mathrm{x}}$ Disease incidence and severity were assessed on 50 potato stems collected from each plot 110 days after planting (except for experiment 6 which lasted 90 days). Stems were rated for disease severity on a scale of 0 to $3: 0=$ no disease symptoms; $3=$ dead plant with microsclerotia on the stem.

y Potato tubers were collected and weighed 130 days after planting.

${ }^{z}$ Values in each column, for each location, followed by the same letter are not significantly different $(P \leq 0.05)$ according to Tukey's multiple range test. 


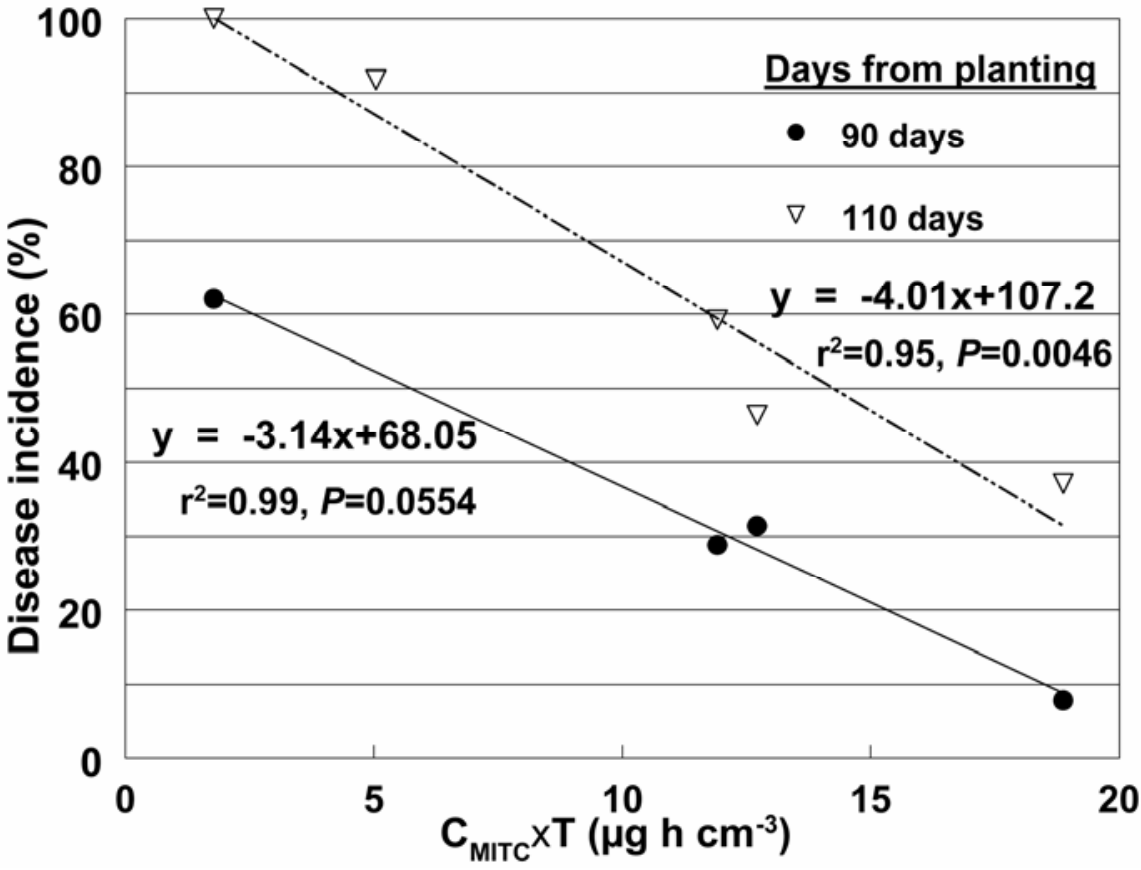

Fig. 5. Relationship between methyl isothiocyanate (MITC) concentration by time $\left(C_{\text {MITC }} \times T\right)$ products calculated from area under the generation-dissipation curve for each soil under controlled laboratory conditions, and incidence of Verticillium wilt in potato field plots, 90 or 110 days after planting, in the field from which the soil sample was taken.

tionship between the $C_{\mathrm{MITC}} \times T$ obtained in the laboratory with MS performance in potato fields.

A significant relationship was found between $C_{\text {MITC }} \times T$ products determined in soil samples brought from the field and tested in the laboratory, and the incidence of Verticillium wilt in these field experiments 110 days after planting (Fig. 5). For example, in experiments $1,2,5$, and 6 (Table 2), in which disease reduction by MS was low (0 to 40\%), both the values of the $C_{\text {MITC }} \times T$ products and the mortality of the test organism under controlled conditions (Table 1) were relatively low. In contrast, in experiments 3, 4, and 7, stronger disease control and higher values of the $C_{\text {MITC }} \times T$ products and of the test organism mortality were obtained. However, no significant relationship was found between disease incidence and test organism mortality when the test was carried out in the field (Fig. 4B). Apparently, this is due to the variations in external conditions prevailing during the tests when carried out in the various fields. Thus, it is preferable to bring the soil samples to the laboratory and test them under similar and controlled conditions.

The combination of MS-formalin was frequently more effective than MS alone, as shown in our study in controlling disease incidence and in increasing tuber yield. This combination was shown to be more effective than either chemical alone (14) and should be used whenever a heavy infestation is expected. The appropriate combined application of different methods such as fumigants and solarization can improve pathogen control (11), and this approach should be at the heart of integrated disease management.

\section{ACKNOWLEDGMENTS}

We thank the field staff of the Alumim, Beeri, En Hashelosha, and Har Hebron Corporation for their valuable assistance in the field experiments; Victor Zilberg, Marina Beniches, Jehudith Rivan, Eyal Klein, Erez Zehavi, and Ofer Heiman for their technical assistance; Dor Chemicals for providing the formalin; and Agan-Makhteshim for providing the metam sodium. This research was supported by grants from the Chief Scientist of the Israeli Ministry of Agriculture and Rural Development. Mention of a proprietary product does not constitute an endorsement or recommendation by the Israeli Ministry of Agriculture, nor does it imply the lack of efficacy of similar products not mentioned. Contribution 703/06 series from the Agricultural Research Organization, the Volcani Center, Bet Dagan, Israel.

\section{LITERATURE CITED}

1. Ajwa, H. A., Trout, T., Mueller, J., Wilhelm, S., Nelson, S. D., Soppe, R., and Shatley, D. 2002. Application of alternative fumigants through drip irrigation systems. Phytopathology 92:1349-1355.

2. Ashley, M. G., Leigh, B. L., and Lloyd, L. S. 1963. The action of metham-sodium in soil. II - Factors affecting the removal of methyl isothiocyanate residues. J. Sci. Food Agric. 14:153-161.

3. Ausher, R., Katan, J., and Ovadia, S. 1975. An improved selective medium for the isolation of Verticillium dahliae. Phytoparasitica 3:133137.

4. Austerweil, M., Gamliel, A., Di Primo, P., and Steiner, B. 2002. Elucidation of the behavior of fumigants in soil by solid microextraction (SPME) and gas liquid chromatography (GC). Proc. IUPAC Congr. Chem. Crop Prot., 10th. August 4-9, Basel, Switzerland, Vol. 2:37

5. Beulke, S., Dubus, I. G., Brown, C. D., and Gottesburen, B. 2000. Simulation of pesticide persistence in the field on the basis of laboratory data - a review. J. Environ. Qual. 29:13711379.

6. Boesten, J. J. T. I., van der Pas, L. J. T., Smelt, J. H., and Leistra, M. 1991. Transformation rate of methyl isothiocyanate and 1,3-dichloropropene in water-saturated sandy subsoils. Neth. J. Agric. Sci. 39:179-190.

7. Browne, G. T., DeTar, W. R., Sanden, B. L., and Phene, C. J. 2002. Comparison of drip and sprinkler irrigation systems for applying metam sodium and managing stem rot on potato. Plant Dis. 86:1211-1218.

8. Call, F., and Hague, N. G. M. 1962. The relationship between the concentration of ethylene dibromide and nematicidal effects in soil fumigation. Nematologia 7:186-192.

9. Di Primo, P., Gamliel, A., Austerweil, M., Steiner, B., Beniches, M., Peretz-Alon, I., and Katan, J. 2003. Accelerated degradation of metam-sodium and dazomet in soil: Characterization and consequences for pathogen control. Crop Prot. 22:635-646.

10. Dungan, R. S., Gan, J., and Yates, S. R. 2003. Accelerated degradation of methyl isothiocyanate in soil. Water Air Soil Pollut. 142:299310.

11. Eshel, D., Gamliel, A., Grinstein, A., Di Primo, P., and Katan, J. 2000. Combined soil treatments and sequence of application in improving the control of soilborne pathogens. Phytopathology 90:751-757.

12. Eshel, D., Gamliel, A., Grinstein, A., and Katan, J. 1999. Evaluation of soil fumigants on soilborne fungal pathogens in a controlledenvironment system and in soil. Crop Prot 18:437-443.

13. Gamliel, A., and Katan, J. 1991. Involvement of fluorescent pseudomonads and other microorganisms in increased growth response of plants in solarized soils. Phytopathology 81:494-502.

14. Gamliel, A., Triky, S., Austerweil, M., Di Primo, P., Beniches, M., Steiner, B., PeretzAlon, I., and Ucko, O. 2005. Combined soil fumigants: Synergistic performance and improved yield. Acta Hortic. 698:135-140.

15. Gan, J., Papiernik, S. K., Yates, S. R., and Jury, W. A. 1999. Temperature and moisture effects on fumigant degradation in soil. J. Environ. Qual. 28:1436-1441.

16. Gerstl, Z., Mingelgrin, U., and Yaron, B. 1977. Behaviour of Vapam and methylisothiocyanate in soils. Soil. Sci. Soc. Am. J. 41:545-548.

17. Helling, C. S. 1971. Pesticide mobility in soils. III. Influence of soil properties. Soil Sci. Soc. Am. Proc. 35:743-748.

18. Kenaga, E. E. 1961. Time, temperature and dosage relationships of several insecticidal fumigants. J. Econ. Entomol. 54:537-542.

19. Knight, H. 1925. Factors affecting efficiency in fumigation with hydrocyanic acid. Hilgardia $1: 35-56$.

20. Munnecke, D. E., Bricker, J. L., and Kolbezen, M. J. 1974. Dosage response of Phytophthora cinnamomi to methyl bromide. Phytopathology 64:1007-1009.

21. Munnecke, D. E., and van Gundy, S. D. 1979. Movement of fumigants in soil, dosage responses, and differential effects. Annu. Rev. Phytopathol. 17:405-429.

22. Munro, H. A. U. 1969. Manual of fumigation for insect control - 2nd rev. ed.. Pages 5-144 in: FAO Studies, No. 79.

23. Rowe, R. C., and Powelson, M. L. 2002. Potato early dying: Management challenges in a changing production environment. Plant Dis. 86:1184-1193.

24. Saeed, I. A. M., Rouse, D. I., Harkin, J. M., and Smith, K. P. 1997. Effects of soil water content and soil temperature on efficacy of metam-sodium against Verticillium dahliae. Plant Dis. 81:773-776.

25. Smelt, J. H., and Leistra, M. 1974. Conversion 
of metham-sodium to methyl isothiocyanate and basic data on the behaviour of methyl isothiocyanate in soil. Pestic. Sci. 5:401-407.

26. Sun, Y. P. 1946. An analysis of some important factors affecting the results of fumigation tests on insects. Minn. Agric. Exp. Tech. Bull. 177.

27. Tomlin, C. 1994. The Pesticide Manual - 10th ed. British Crop Protection Council, Surry, UK.

28. Tsror, L., Shlevin, E., and Peretz-Alon, I. 2005.
Efficacy of metam sodium for controlling Verticillium dahliae prior to potato production in sandy soils. Am. J. Potato Res. 82:419-423.

29. Turner, N. J., and Corden, M. E. 1963. Decomposition of sodium $\mathrm{N}$-Methyldithiocarbamate in soil. Phytopathology 53:13881394.

30. Wang, D., and Yates, S. R. 1999. Spatial and temporal distributions of 1,3-dichloropene in soil under drip and shank application and im- plications for pest control efficacy using concentration-time index. Pestic. Sci. 55:154-160.

31. Warton, B., and Matthiessen, J. N. 2005. The crucial role of calcium interacting with soil $\mathrm{pH}$ in enhanced biodegradation of metam sodium Pestic. Manag. Sci. 61:856-862.

32. Warton, B., Matthiessen, J. N., and Roper, M. M. 2001. The soil organisms responsible for the enhanced biodegradation of metam sodium. Biol. Fertil. Soils. 34:264-269. 